\title{
Budaya Organisasi yang Mendukung Keselamatan Pasien di Rumah Sakit
}

\author{
Ari Widyanti ${ }^{* *}$, Anisa Agtriani ${ }^{1}$
}

\begin{abstract}
Organizational culture is one of important factors that contribute to the performance of an organization, including in a hospital. In a hospital, performance can be measured by its level of patient safety. Howover, studies and research that discuss the relationship of organizational culture and patient safety are still very limited, including in Indonesia. This research is conducted to observe organizational culture that support patient safety. This research is conducted in three hospitals in Jakarta. Type of organizational culture is identified using the Organizational Culture Assessment Instrument (OCAI) questionnaire and the level of patient safety is assessed using the Hospital Survey on Patient Safety Culture (HSOPSC) questionnaire. Once the organizational culture is identified and the level of patient safety culture is observed in each hospital, correlation test and analysis is conducted between types of organizational culture with aspect of patient safety based. Results show that three hospitals do not have dominant organizational culture. However, type of organizational culture that has a significant positive correlation with aspect of patient safety the most is adhocracy culture, eventhough other organizational culture type also support patient safety. The result of this research then used as initial suggestion to make change on organizational culture so that patient safety could be improved.
\end{abstract}

Keywords: Organizational culture, patient safety, OCAI, HSOPSC.

\section{Pendahuluan}

Keselamatan pasien di rumah sakit merupakan isu yang sering muncul dewasa ini. Menurut UU RI No. 44 Tahun 2009 [1], rumah sakit adalah institusi pelayanan kesehatan yang menyelenggarakan pelayanan kesehatan perorangan secara paripurna yang menyediakan pelayanan rawat inap, rawat jalan, dan gawat darurat. Namun, Lembaga Bantuan Hukum Kesehatan Pusat pada tahun 2009 yang mencatat kurang lebih terdapat 150 kasus yang berhubungan dengan keselamatan pasien di RS di Indonesia (Yunanto [2]). Hal tersebut menggarisbawahi tugas rumah sakit untuk selalu mengutamakan dan meningkatkan keselamatan pasien dalam pelayanan yang diberikan.

Menurut Peraturan Menteri Kesehatan RI No. 1691/Menkes/PER/VIII/2011 [3], keselamatan pasien adalah "sistem pelayanan dalam suatu rumah sakit yang memberikan asuhan pasien menjadi lebih aman yang meliputi penilaian risiko, identifikasi dan pengelolaan hal yang berhubungan dengan risiko pasien, pelaporan dan analisis insiden, kemampuan belajar dari insiden dan tindak lanjutnya serta implementasi solusi untuk meminimalkan timbulnya risiko dan mencegah terjadinya cedera yang disebabkan oleh kesalahan akibat melaksanakan suatu tindakan atau tidak mengambil tindakan yang seharusnya diambil".

1 Fakultas Teknologi Industri, Program Studi Teknik Industri, Institut Teknologi Bandung, Jl. Ganesa 10 Bandung 40132, Indonesia. Email: widyanti@mail.ti.itb.ac.id.

* Penulis korespondensi
Menurut Gaba [4] serta Battles dan Lilford [5] keselamatan pasien adalah sistem pencegahan dan perbaikan dari kejadian yang tidak diinginkan atau bahaya yang dapat terjadi dalam proses pelayanan kesehatan. Oleh karena keselamatan pasien merupakan suatu proses yang harus diupayakan, maka penelitian yang bertujuan untuk meningkatkan keselamatan pasien mutlak diperlukan.

Keselamatan pasien di rumah sakit dipengaruhi oleh berbagai faktor. Chiu, et al. [6] menyebutkan faktor yang mempengaruhi keselamatan pasien di RS antara lain faktor karakteristik organisasi seperti budaya organisasi, budaya kepemimpinan, tingkat keikutsertaan pemimpin, komunikasi, partisipasi pasien dan keluarga, dan manajemen pemberdayaan sumber daya manusia. Diantara karakteristik organisasi tersebut, budaya organisasi merupakan salah satu faktor penting yang menjadi perhatian dalam suatu institusi termasuk rumah sakit (contoh Edy [7]). Lebih jauh, Davies [8] menyatakan, bahwa melalui budaya organisasi, suatu organisasi dapat memunculkan sikap dan perilaku anggota organisasi. Berkaitan dengan rumah sakit, budaya organisasi berarti memunculkan perilaku dan juga lingkungan yang mendukung keselamatan pasien.

Definisi budaya organisasi menurut Cushway dan Lodge [9] merupakan sistem nilai organisasi yang akan mempengaruhi bagaimana pekerjaan suatu organisasi diselesaikan dan bagaimana anggota organisasi berperilaku. Menurut Robbins [10], budaya organisasi merupakan suatu sistem nilai yang 
dipegang dan diterapkan oleh anggota organisasi, sehingga setiap organisasi bisa memiliki budaya yang berbeda. Definisi budaya organisasi yang terbaru, yang mencakup definisi dari Cushway dan Lodge [9] serta Robbins [10] dan digunakan dalam penelitian ini mengacu pada definisi Cameron dan Quinn [11] yang menyatakan bahwa budaya organisasi ditunjukkan melalui nilai-nilai khusus yang dimiliki organisasi meliputi bahasa dan simbol, aturan dan kebiasaan, dan definisi sukses yang membuat suatu organisasi unik. Budaya organisasi dapat digunakan untuk membedakan antara satu organisasi dengan organisasi yang lain.

Di negara maju, perhatian besar ditunjukkan terhadap keselamatan pasien di rumah sakit, diantaranya melalui pendekatan budaya organisasi. Hal ini dibuktikan dengan berbagai hasil penelitian yang telah dilakukan untuk mengetahui hubungan antara budaya organisasi dengan keselamatan pasien di rumah sakit. Singer, et al. [12] melakukan studi eksploratif mengenai aspek budaya organisasi berkaitan dengan iklim keselamatan pasien di rumah sakit. Westrum [13] melakukan penelitian awal yang menunjukkan bahwa budaya organisasi memiliki hubungan dengan keselamatan dan jenis budaya organisasi tertentu dapat meningkatkan keselamatan. Hartmann [14] menyatakan bahwa budaya kelompok dan enterpreneurial yang lebih tinggi berkaitan dengan tingkat keselamatan yang lebih baik, sedangkan budaya hierarki berhubungan dengan keluaran yang lebih buruk. Speroffl et al. [15] menunjukkan variasi budaya organisasi di rumah sakit yang berpengaruh terhadap keselamatan pasien di rumah sakit.

Penelitian serupa di negara berkembang termasuk di Indonesia masih sangat terbatas dikarenakan berbagai hal. Di Cina, penelitian yang dilakukan oleh Chiu, et al. [6] menunjukkan bahwa budaya organisasi yang mendukung keselamatan pasien di rumah sakit adalah budaya hierarki. Hal ini bertolak belakang dengan hasil penelitian di negara maju. Hal ini mendorong perlunya penelitian serupa di negara berkembang. Selain itu, penelitian mengenai keselamatan pasien di rumah sakit di Indonesia masih sangat terbatas. Penelitian mengenai keselamatan pasien di rumah sakit di Indonesia masih terbatas pada penelitian yang dilakukan terhadap kinerja perawat (Setiowati [16]), penelitian mengenai persepsi terhadap layanan rumah sakit (contoh Hikmah [17]), dan penelitian mengenai kepemimpinan dan budaya keselamatan pasien di rumah sakit (Sagala dan Widyanti [18]). Oleh karena itu, perlu dilakukan penelitian untuk mengetahui budaya organisasi yang mendukung keselamatan pasien di RS sebagai upaya meningkatkan keselamatan pasien di rumah sakit di Indonesia.

\section{Metode Penelitian}

\section{Responden Penelitian}

Penelitian ini dilakukan di tiga rumah sakit di Jakarta. Pemilihan rumah sakit sebagai responden dilakukan dengan metode convenience sampling dengan mendasarkan pada rumah sakit yang memberikan ijin dalam pengambilan data. Kuesioner yang digunakan dalam pengambilan data diisi oleh perwakilan unit kerja di rumah sakit. Respond rate (persentase jumlah kuesioner yang kembali dibandingkan dengan kuesioner yang disebarkan adalah $82 \%$ untuk OCAI dan 93\% untuk HSOPSC. Total jumlah kuesioner untuk HSOPSC adalah 37, 27, dan 55 untuk rumah sakit A, B, dan C. Total jumlah kuesioner untuk OCAI adalah 34, 33, dan 31 untuk rumah sakit $\mathrm{A}, \mathrm{B}$, dan $\mathrm{C}$.

\section{Tools Pengambilan Data}

Tools yang digunakan dalam penelitian ini berupa kuesioner, yaitu kuesioner Organizational Culture Assessment Instrument (OCAI) dan Hospital Survey on Patient Safety (HSOPSC). OCAI yang digunakan merupakan kuesioner yang sudah diterjemahkan dalam bahasa Indonesia dan sudah terbukti valid dan reliabel (Rangkuti, [19]). Kuesioner HSOPSC versi bahasa Inggris diterjemahkan melalui proses back translation dan diuji validitas dan reliabilitasnya (lihat Brislin [20], Johnson dan Widyanti [21]). Pengujian validitas dan reliabilitas dilakukan dengan perhitungan chronbach alpha dengan nilai $<0,05$. Semua item dalam OCAI memiliki reliabilitas dan validitas $>0,7$.

OCAI (Cameron dan Quinn, [11]) mengukur enam dimensi budaya yaitu karakteristik dominan organisasi, kepemimpinan organisasi, manajemen personil, perekat organisasi, kriteria keberhasilan organisasi, dan strategi yang ditekankan oleh organisasi. Kuesioner OCAI terdiri dari dua kolom, yaitu kolom penilaian 'Saat ini' dan kolom penilaian 'Harapan'. Setiap bagian terdiri dari 4 pernyataan, yaitu pernyataan yang mewakili budaya klan, pernyataan yang mewakili budaya adhokrasi, pernyataan yang mewakili budaya pasar, dan pernyataan yang mewakili budaya hierarki. Budaya klan dicirikan dengan lingkungan organisasi yang dapat diatur melalui kerja sama tim dan pengembangan sumber daya manusia, serta organisasi yang mengutamakan kerja sama, partisipasi, dan konsensus. Budaya adhokrasi bersifat entrepreneurial, dimana setiap individu di dalam organisasi bertanggung jawab dan harus berani mengambil risiko dan berinisiatif. Budaya pasar berorientasi pada target, bersifat kompetitif dan penuh tuntutan berprestasi. Budaya organisasi hierarki 
dicirikan dengan organisasi yang memiliki tempat kerja yang formal dan terstruktur, terdapat standar prosedur untuk melakukan sesuatu.

Keempat pernyataan harus dinilai oleh responden dengan range penilaian 0-100 sehingga jumlah nilai keempat pernyataan harus sama dengan 100. Cara penilaian yang dilakukan adalah dengan menilai keempat pernyataan di enam bagian yang total keempat nilai tersebut harus 100. Penilaian tertinggi diberikan pada pernyataan yang paling sesuai dengan organisasi yang sedang di nilai.

Budaya organisasi yang dikatakan dominan adalah budaya organisasi yang memiliki skor yang paling besar. Menurut Cameron dan Quinn [11] budaya organisasi yang dominan dapat dikatakan sebagai budaya organisasi yang kuat (perbedaan bermakna) jika selisih skor budaya dominan dengan budaya lainnya lebih besar dari 10 poin. Semakin kuat budaya organisasi, maka kerja organisasi akan semakin homogen dan jelas, tetapi pada ciri budaya organisasi yang kuat akan menyebabkan semakin sulitnya merubah budaya organisasi tersebut (Westrum [13]).

Hospital survey on patient safety culture (HSOPSC) merupakan instrumen penilaian budaya keselamatan pasien yang dirancang dan dikembangkan oleh Agency for Healthcare Research (AHRQ), Amerika Serikat. Instrumen HSOPSC terdiri dari enam bagian penilaian, yaitu penilaian unit kerja, penilaiaan manajer/supervisor, komunikasi, frekuensi laporan suatu event, peringkat keselamatan pasien, dan penilaian rumah sakit. Kuesioner HSOPSC memiliki skala likert 1-4 (1=sangat tidak setuju, $4=$ sangat setuju). Dari enam bagian penilaian tersebut, instrumen HSOPSC menekankan penilaian pada isu keselamatan pasien, kesalahan (error), dan pelaporan kejadian. Instrumen ini mengukur tujuh aspek budaya keselamatan pada level unit sebagai berikut: (1) Harapan-harapan dan tindakan-tindakan supervisor/manajer dalam mempromosikan keselamatan pasien (patient safety) misalnya melalui pelaporan kesalahan dan pemberian perhatian terhadap isu keselamatan pasien. (2) Pembelajaran organisasi dan peningkatan yang berkelanjutan, staf berperan aktif dan selalu ada upaya dalam meningkatkan keselamatan pasien. (3) Kerja tim di dalam unit rumah sakit. Adanya kerjasama individu dalam meningkatkan keselamatan pasien. (4) Keterbukaan komunikasi. Adanya kebebasan bertanya dan berpendapat dalam kaitannya dengan keselamatan pasien. (5) Feedback dan komunikasi mengenai kesalahan (error). Adanya informasi yang bersifat dua arah dalam kaitannya dengan keselamatan pasien. (6) Respon tidak menghukum ketika terjadi kesalahan (non punitive response to error) tidak semua kesalahan berakibat pada pemberian hukuman. (7) Staffing, kuantitas dan kualitas staf memadai.

Hasil rekapitulasi kuesioner HSOPSC kemudian diolah untuk mendapatkan skor hasil setiap item pernyataan. Perhitungan skor item pernyataan positif dilakukan dengan cara sebagai berikut:

$\frac{\# \text { Pernyataan sangat setuju }+\# \text { Pernyataan setuju }}{\text { Total jumlah pernyataan positif dan negatif }} \times 100 \%$

Perhitungan skor item pernyataan negatif dilakukan dengan cara sebagai berikut:

\#Pernyataan sangat tdk setuju + \#Pernyataan tdk setuju $\times 100 \%$

Penilaian setiap item pernyataan digolongkan sebagai berikut: 'baik' jika skor yang didapatkan lebih besar atau sama dengan $75 \%$, 'cukup' jika skor yang didapatkan berada diantara 50\%-75\%, 'kurang dan memerlukan perbaikan' jika skor yang didapatkan berada di bawah $50 \%$.

\section{Hasil dan Pembahasan}

Pada Tabel 1 dapat dilihat bahwa aspek penilaian keselamatan di ketiga rumah sakit memiliki nilai lebih dari $60 \%$ atau sudah cukup baik. Masingmasing RS memiliki nilai aspek keselamatan pasien di bawah 50\% yang menunjukkan potensi perbaikan yang harus diperhatikan oleh masing-masing $\mathrm{RS}$ dalam meningkatkan keselamatan pasien di RS.

Oleh karena jumlah data yang terbatas pada tiga RS, uji korelasi tidak dilakukan. Oleh karena itu digunakan analisis deskriptif budaya organisasi dan aspek keselamatan RS sebagai berikut:

\section{Keselamatan Pasien dengan Budaya Klan}

Budaya klan berkaitan terhadap pembelajaran organisasi, feedback dan komunikasi mengenai kesalahan, dan respon tidak menghukum ketika terjadi kesalahan. Hal tersebut dapat terjadi karena budaya klan memberikan lingkungan kerja yang nyaman dan menempatkan pemimpin sebagai mentor atau bahkan seperti figur orang tua, yang mana membuat para staf di rumah sakit merasa lebih santai untuk melakukan evaluasi sebagai pembelajaran organisasi. Akibatnya hasil pembelajaran organisasi tidak terlalu signifikan dan komunikasi mengenai kesalahan yang terjadi juga dilakukan kurang formal sehingga tidak dilaporkan dengan lengkap dan jelas. Selain itu, budaya klan juga dapat membuat para staf memiliki rasa takut dihukum ketika terjadi kesalahan karena pemimpin yang dianggap seperti figur orang tua tidak akan 
Tabel 1. Hasil pengukuran budaya organisasi dan keselamatan pasien di tiga rumah sakit

\begin{tabular}{|c|c|c|c|c|c|c|}
\hline \multirow{2}{*}{$\begin{array}{c}\text { Rumah } \\
\text { sakit }\end{array}$} & \multicolumn{2}{|c|}{ Budaya organisasi } & \multicolumn{4}{|c|}{ Keselamatan pasien } \\
\hline & $\begin{array}{c}\text { Budaya dengan } \\
\text { nilai tertinggi }\end{array}$ & Nilai & Aspek penilaian & Nilai & Aspek keselamatan pasien & Nilai \\
\hline \multirow[t]{14}{*}{$\mathrm{A}$} & Hierarki & 27,88 & Outcome & $65,91 \%$ & Frekuensi pelaporan & $40,00 \%$ \\
\hline & & & measured & & Persepsi keselamatan pasien & $77,73 \%$ \\
\hline & & & & & Peringkat keselamatan pasien & $80,00 \%$ \\
\hline & & & Unit kevel & $80,65 \%$ & Harapan dan tindakan manajer & $83,18 \%$ \\
\hline & & & & & Pembelajaran organisasi & $98,18 \%$ \\
\hline & & & & & Kerja tim di dalam unit & $95,91 \%$ \\
\hline & & & & & Komunikasi & $89,09 \%$ \\
\hline & & & & & Feedback dan komunikasi mengenai & \\
\hline & & & & & kesalahan & $90,91 \%$ \\
\hline & & & & & Non punitive response to error & $54,55 \%$ \\
\hline & & & & & Staffing & $52,73 \%$ \\
\hline & & & Hospital wide & $86,92 \%$ & Dukungan manajemen RS & $88,48 \%$ \\
\hline & & & & & Kerja tim antar unit & $88,64 \%$ \\
\hline & & & & & Penyerahan dan pemindahan pasien & $83,64 \%$ \\
\hline \multirow[t]{14}{*}{$\mathrm{B}$} & Pasar & 26,09 & Outcome & $69,70 \%$ & Frekuensi pelaporan & $29,52 \%$ \\
\hline & & & measured & & Persepsi keselamatan pasien & $82,43 \%$ \\
\hline & & & & & Peringkat keselamatan pasien & $97,14 \%$ \\
\hline & & & Unit level & $78,86 \%$ & Harapan dan tindakan manajer & $86,49 \%$ \\
\hline & & & & & Pembelajaran organisasi & $96,40 \%$ \\
\hline & & & & & Kerja tim di dalam unit & $92,57 \%$ \\
\hline & & & & & Komunikasi & $86,49 \%$ \\
\hline & & & & & Feedback dan komunikasi mengenai & \\
\hline & & & & & kesalahan & $90,09 \%$ \\
\hline & & & & & Non punitive response to error & $44,14 \%$ \\
\hline & & & & & Staffing & $55,86 \%$ \\
\hline & & & Hospital wide & $88,29 \%$ & Dukungan manajemen RS & $89,19 \%$ \\
\hline & & & & & Kerja tim antar unit & $90,54 \%$ \\
\hline & & & & & Penyerahan dan pemindahan pasien & $85,14 \%$ \\
\hline \multirow[t]{14}{*}{$\mathrm{C}$} & Klan & 27,28 & Outcome & $71,32 \%$ & Frekuensi pelaporan & $53,15 \%$ \\
\hline & & & measured & & Persepsi keselamatan pasien & $77,03 \%$ \\
\hline & & & & & Peringkat keselamatan pasien & $83,78 \%$ \\
\hline & & & Unit level & $75,77 \%$ & Harapan dan tindakan manajer & $83,78 \%$ \\
\hline & & & & & Pembelajaran organisasi & $90,09 \%$ \\
\hline & & & & & Kerja tim di dalam unit & $95,27 \%$ \\
\hline & & & & & Komunikasi & $86,49 \%$ \\
\hline & & & & & Feedback dan komunikasi mengenai & \\
\hline & & & & & kesalahan & $85,59 \%$ \\
\hline & & & & & Non punitive response to error & $37,48 \%$ \\
\hline & & & & & Staffing & $51,35 \%$ \\
\hline & & & Hospital wide & $86,04 \%$ & Dukungan manajemen RS & $86,49 \%$ \\
\hline & & & & & Kerja tim antar unit & $85,81 \%$ \\
\hline & & & & & Penyerahan dan pemindahan pasien & $85,81 \%$ \\
\hline
\end{tabular}

menghukum, tetapi memberi peringatan dan membantu memperbaiki kesalahan yang dilakukan. Budaya klan juga berkaitan dengan aspek penyerahan dan pemindahan pasien. Hal tersebut dapat disebabkan budaya klan yang sangat mengutamakan kerja sama sehingga lingkungan organisasi yang teratur akan membantu terlaksananya penyerahan dan pemindahan pasien dengan lebih baik. Hasil ini sejalan dengan hasil penelitian yang dilakukan oleh Cameron dan Quinn [11].

\section{Keselamatan Pasien dengan Budaya Adhokrasi}

Budaya adhokrasi berkaitan dengan frekuensi pelaporan kejadian, persepsi keselamatan pasien, komunikasi, staffing, dukungan manajemen rumah sakit, dan kerja tim antar unit. Budaya adhokrasi identik dengan tempat kerja yang dinamis dan bersifat entrepreneurial yang membuat setiap individu di dalam organisasi bertanggung jawab dan berani mengambil risiko membuat para staf rumah sakit sangat aware bahwa tempat kerja mereka memiliki tujuan untuk memberikan pelayanan kesehatan yang lebih baik dibandingkan dengan rumah sakit lainnya sehingga para staf rumah sakit sangat mengutamakan keselamatan pasien. Selain itu, budaya adhokrasi mendorong individu di dalam organisasi untuk berinisiatif membuat para staf lebih sigap dalam melaporkan suatu kejadian. Hasil tersebut juga sesuai dengan penelitian yang sudah ada yang menyatakan bahwa budaya entrepreneurial memiliki pengaruh yang baik 
untuk keselamatan (Hartmann et al. [14]) dan budaya entrepreneurial yang lebih dominan berkaitan dengan iklim keselamatan yang lebih baik, hal tersebut mungkin disebabkan budaya entrepreneurial akan memperkuat instansi lokal dan memperkenalkan cara bekerja berkelompok serta memecahkan masalah yang dibutuhkan untuk mengambil langkah yang efektif dan holistik untuk memahami dan menyelesaikan akar dari suatu masalah (Tucker dan Edmondson [22]; Edmondson et al. [23]).

\section{Keselamatan Pasien dengan Budaya Pasar}

Budaya pasar berkaitan dengan frekuensi pelaporan kejadian, persepsi keselamatan pasien, staffing, dukungan manajemen rumah sakit, dan kerja tim antar unit. Organisasi dengan budaya pasar memiliki pimpinan yang mendorong staf untuk berprestasi, produktif, dan kompetitif (Cameron dan Quinn[11]). Dengan demikian, di dalam rumah sakit yang memiliki budaya pasar yang tinggi akan memiliki dukungan manajemen rumah sakit yang sangat tinggi karena pemimpin ingin rumah sakitnya memiliki reputasi yang baik dengan memiliki tingkat keselamatan pasien yang baik. Dukungan manajemen rumah sakit dalam mewujudkan keselamatan pasien yang baik juga akan membuat para staf memiliki kesadaran bahwa keselamatan pasien adalah hal yang utama sehingga persepsi keselamatan pasien secara keseluruhan akan didapatkan lebih baik. Hasil ini sedikit bertentangan dengan teori yang menyatakan bahwa individu di dalam organisasi dengan dominasi budaya pasar saling berkompetisi dan berorientasi pada target (Cameron dan Quinn [11]). Hal tersebut mungkin dapat disebabkan lingkungan kerja di rumah sakit yang menuntut kerja sama yang baik untuk memberikan pelayanan kepada pasien sehingga walaupun budaya pasar tinggi, namun setiap staf tetap bekerja sama untuk memberikan pelayanan yang aman kepada pasien.

\section{Keselamatan Pasien dengan Budaya Hierarki}

Budaya hierarki berkaitan dengan harapan dan tindakan manajer dan kerja tim di dalam unit. Hasil tersebut mungkin didapatkan karena organisasi dengan budaya hierarki yang dominan memiliki tempat kerja yang formal dan terstruktur, standar prosedur untuk setiap pekerjaan, dan pemimpin yang dianggap sebagai koordinator (Cameron dan Quinn [11]). Dengan karakteristik budaya hierarki seperti itu, maka harapan dan tindakan manajer terhadap aspek keselamatan pasien dapat diperoleh karena manajer sebagai pemimpin dipercaya sebagai ahli organisasi yang mementingkan efektivitas akan sangat memperhatikan masalah keselamatan pasien di rumah sakit sebagai tujuan organisasi. Pemimpin organisasi dengan budaya hierarki, berdasarkan teori, akan selalu mengikuti kebijakan-kebijakan yang ada sehingga harapan dan tindakan tentang keselamatan pasien akan diperoleh lebih baik selama manajer mengikuti kebijakan mengenai keselamatan pasien. Selain itu, posisi pemimpin sebagai koordinator juga membuat kerja tim di dalam unit rumah sakit dengan budaya hierarki lebih baik. Hal tersebut dikarenakan pemimpin melakukan pengaturan yang harus diikuti oleh para staf yang dibawahinya sehingga kerja sama yang baik dapat terbentuk. Hasil penelitian ini tidak sejalan dengan hasil penelitian Caroll et al. [24] dan Shortell [25] yang menyatakan bahwa budaya hierarki berkorelasi negatif dengan budaya keselamatan pasien. Namun perlu digaris bawahi bahwa penelitian Caroll et al. [24] dan Shortell [25] lebih mengedepankan kecilnya kemungkinan dilanggarnya aturan berkaitan dengan keselamatan.

Hasil penelitian ini menunjukkan bahwa tidak terdapat budaya organisasi spesifik yang berkaitan atau mendukung keselamatan pasien di rumah sakit. Aspek budaya organisasi yang berbeda dari setiap tipe budaya organisasi berkaitan dengan aspek keselamatan pasien yang berbeda. Hal ini sejalan dengan penelitian Speroffl et al. [15] yang menunjukkan variasi budaya organisasi yang mendukung keselamatan pasien di rumah sakit. Hartman et al. [14] juga mengulas beberapa penelitian yang menunjukkan bahwa kombinasi antara berbagai tipe budaya organisasi akan berimplikasi pada keselamatan pasien di rumah sakit.

Meskipun penelitian ini belum mengidentifikasi kombinasi optimal dari tipe budaya organisasi yang mendukung keselamatan pasien di rumah sakit, penelitian ini memberikan beberapa masukan untuk rumah sakit yang ingin meningkatkan keselamatan pasien melalui pendekatan budaya organisasi. Budaya adhokrasi yang bercirikan entrepreneural yang dalam penelitian ini merupakan budaya organisasi yang paling banyak berkaitan dengan keselamatan pasien di rumah sakit, merupakan budaya yang harus ditingkatkan. Hal ini sejalan dengan hasil beberapa penelitian sebelumnya (Hartman, et al. [14]).

Penelitian ini memiliki keterbatasan. Pertama, jumlah rumah sakit yang menjadi responden hanya tiga rumah sakit. Hal ini dikarenakan sulitnya mendapatkan ijin dari rumah sakit berkaitan dengan isu keselamatan pasien yang ternyata masih menjadi isu yang sangat sensitif dan menjadi hal yang bersifat rahasia di rumah sakit. Keterbatasan yang kedua adalah tidak semua pejabat di rumah 
sakit menjadi responden dalam penelitian ini karena alasan teknis. Variasi jabatan yang representatif harus dilakukan untuk penelitian selanjutnya. Dalam penelitian ini, variasi jabatan yang mengisi kuesioner tidak cukup banyak karena kurangnya kerja sama yang baik dengan pihak rumah sakit selama pengambilan data.

\section{Simpulan}

Dalam penelitian ini, ketiga rumah sakit yang menjadi responden tidak memiliki budaya yang dominan karena selisih nilai antar tipe budaya tidak lebih dari 10. Tidak terdapat budaya organisasi yang berkaitan dengan semua aspek keselamatan pasien, yang berarti bahwa budaya organisasi yang mendukung keselamatan pasien merupakan kombinasi dari budaya organisasi yang ada yang spesifik untuk aspek keselamatan pasien yang tertentu. Namun, budaya adhokrasi yang bercirikan entrepreneur merupakan budaya organisasi yang paling banyak berkaitan dengan keselamatan pasien di rumah sakit.

\section{Daftar Pustaka}

1. Republik Indonesia,UU Nomor 44 Tahun 2009 tentang Rumah Sakit, 2009.

2. Yunanto, H., Pertanggungjawaban Dokter pada Transaksi Terapeutik, Thesis, Universitas Diponegoro, Semarang, 2009.

3. Republik Indonesia, Peraturan Menteri Kesehatan Republik Indonesia Nomor 1691/Menkes/ Per/VIII/2011, 2011.

4. Gaba, D.M., Structural and Organizational Issues in Patient Safety: A Comparison of Health Care to Other High-hazard Industries, California Management Review, 43, 2000, pp. 83-102.

5. Battles, J.B., and Lilford, R.J., Organizing Patent Safety Research to Identify Risks and Hazards. Qual Saf Health Care, 12(2), 2003, pp. 2-7.

6. Chiu, C.H., Pan, W.H., and Wei, C.J., Does Organizational Culture Impact Patient Safety Management? Asian Journal of Health and Information Sciences, 3(1), 2008, pp. 88-100.

7. Edy, Pengaruh Budaya Organisasi dan Lingkungan Kerja terhadap Kinerja Perawat. Jurnal Ekonomi dan Bisnis, 2(3), 2008, pp. 1978-3116.

8. Davies, H.T., Organizational Culture and Quality of Health Care, Quality for Health Care, 9, 2000, pp. 111-119.

9. Cushway, B., and Lodge, D., Organizational Behaviour and Design, Perilaku dan Desain Organisasi. PT. Elex Media Komputindo, Jakarta, 2000.
10. Robbins, S.P., Essentials of Organizational Behavior, Pearson Education, Inc, New Jersey, 2003.

11. Cameron, K.S., and Quinn, R.E., Diagnosing and Changing Organizational Culture: Based on The Competing Values Framework, JOSEY BASS: A Wiley Imprint, California, 2006.

12. Singer, S.J., Gaba, D.M., Geppert, J.J., Sinaiko, A.D., Howard, S.K., and Park, K.C., The Culture of Safety: Results of an Organization-wide Survey in 15 California Hospitals, Quality \& Safety in Health Care, 12, 2003, pp. 112-118.

13. Westrum, R. A., Typology of Organizational Cultures. Quality \& Safety Health Care, 13, 2004, pp. 22-27.

14. Hartmann, C.W., Meterko, M., Rosen, A.K., Zhao, S., Singer, S., and Gaba, D.M., Relationship of Hospital Organizational Culture to Patient Safety Climate in the Veterans Health Administration, Medical Care Research and Review, 66(3), 2009, pp. 320-338.

15. Speroffl, T., Nwosu, S., Greevy, R., Weinger, M.B., Talbot, T.R., Wall, R.J., Deshpande, J.K., Fance, D.J., Ely, E.W., Burgess, H., Englebright, J., Williams, M.V., and Dittus, R.S., Organisational Culture: Variation across Hospitals and Connection to Patient Safety Climate, Quality Safety Health Care, 19, 2010, pp. 592-596.

16. Setiowati, D., Hubungan Kepemimpinan Efektif HEAD NURSE dengan Penerapan Budaya Keselamatan Pasien oleh Perawat Pelaksana di RSUPN Dr. Ciptomangunkusumo Jakarta, Thesis, Universitas Indonesia, 2010.

17. Hikmah, S., Persepsi Staf mengenai Patient Safety di Instalasi Rawat Darurat RSUP Fatmawati Tahun 2008, Laporan Tugas Akhir, Universitas Indonesia, 2008.

18. Sagala, B.R., dan Widyanti, A., Hubungan antara Kepemimpinan dan Budaya Keselamatan Pasien di Rumah Sakit, Proceeding Seminar Nasional dan Kongres PEI 2015, Yogyakarta, 17-18 Nopember 2015.

19. Rangkuti, F., Kuesioner Organizational Culture Assessment Instrument (OCAI) http://freddyrangkuti.wordpress.com/2011/03/08/kuesionerocai/, 2011, diakses pada 30 Juni 2014.

20. Brislin, R.W., Back-translation for Cross-cultural Research, Journal of Cross-Cultural Psychology, 1(3), 1970, pp. 185-216.

21. Johnson, A., and Widyanti, A., Cultural Influence on the Measurement of Mental Workload. Ergonomics, 54(6), 2011, pp. 509-518.

22. Tucker, A., and Edmondson, A., Why Hospitals Don't Learn from Failures: Organizational and Psychological Dynamics that Inhibit System Change, California Management Review, 45, 2003, pp. 55-72. 
23. Edmondson, A.C., Bohmer, R.M., and Pisano, G.P., Disrupted Routines: Team Learning and New Technology Implementation in Hospitals, Administrative Science Quarterly, 46, 2001, pp. 685-716.

24. Carroll, J.S., Rudolph, J.W., and Hatakenaka, S., Learning from Experience in High-hazard
Organizations, Research in Organizational Behavior, 24, 2002, pp. 87-137.

25. Shortell, S.M., O'Brien, J.L., Carman, J.M., Foster, R.W., Hughes, E.F., Boerstler, H., and O'Connor, E.J., Assessing the Impact of Continuous Quality Impovement/Total Quality Management: Concept versus Implementations, Health Service Research, 30, 1995, pp. 377-401. 